\title{
DETERMINANTS OF VISUAL INSPECTION ACETYL ACID UTILIZATION ON EARLY DETECTION OF CERVICAL CANCER
}

\author{
Elfania Arumma Sunarta1), Endang Sutisna Sulaeman²), \\ Uki Retno Budihastuti3)
}

\author{
1)Masters Program in Public Health, Universitas Sebelas Maret \\ 2)Department of Public Health, Faculty of Medicine, Universitas Sebelas Maret \\ 3)Department of Obstetrics and Gynecology, Dr. Moewardi Hospital, Surakarta
}

\begin{abstract}
Background: Visual inspection acetyl acid (VIA) test is an effective screening test to reduce the risk of cervical cancer. Previous studies using the Health Belief Model (HBM) as a framework have typically found it to be useful in predicting health behavior. However, empirical evidence regarding the application of HBM constructs to predict VIA test utilization behavior remains scant. This study aimed to examine the determinants of VIA utilization on early detection of cervical cancer using HBM model.

Subjects and Method: This was a case control study conducted at Wongsorejo Community Health Center, Banyuwangi, East Java, from February to March 2019. A sample of 200 women of reproductive age was selected by fixed disease sampling. The dependent variable was visual acetic acid use. The independent variables were knowledge, attitude, access, and husband support. The data were collected by questionnaire and analyzed by a multiple logistic regression.

Results: Low VIA screening use was affected by low knowledge (OR=4.70; 95\% CI= 1.99 to $11.09 ; \mathrm{p}<0.001)$, negative attitude $(\mathrm{OR}=3.59 ; 95 \% \mathrm{CI}=1.60$ to $8.04 ; \mathrm{p}=0.002)$, poor access $(\mathrm{OR}=3.18 ; 95 \% \mathrm{CI}=1.34$ to $7.53 ; \mathrm{p}=0.009)$, and weak husband support $(\mathrm{OR}=3.01 ; 95 \% \mathrm{CI}=1.35$ to $6.70 ; \mathrm{p}=0.007)$.
\end{abstract}

Conclusion: Low VIA screening use is affected by low knowledge, negative attitude, poor access, and weak husband support.

Keywords: Visual Acetic Acid, screening Health Belief Model

Correspondence:

Elfania Arumma Sunarta. Masters Program in Public Health, Universitas Sebelas Maret. Jl. Ir. Sutami 36A, Surakarta 57126, Central Java, Indonesia. Email: elfaniaas@gmail.com. Mobile: +6282272434301

The $6^{\text {th }}$ International Conference on Public Health

Best Western Premier Hotel, Solo, Indonesia, October 23-24, 2019 | 153

https://doi.org/10.26911/the6thicph.03.11 